\title{
Behandling av medfødte sammenvokste fingre
}

\begin{abstract}
BAKGRUNN Syndaktyli eller sammenvokste fingre er en av de vanligste medfødte misdannelsene i overekstremitetene, men utgjør få nye tilfeller årlig. Behandlingsmålet er å øke håndens funksjonsnivå.
\end{abstract}

KUNNSKAPSGRUNNLAG Artikkelen er basert på aktuelle lærebøker og litteratursøk i PubMed samt forfatternes kliniske erfaring innen feltet.

RESULTATER Den operative behandlingen har som intensjon å separere fingrene og rekonstruere et mellomrom mellom fingre. Det er vanskelig å angi eksakt behandlingsresultat grunnet store variasjoner i omfanget av misdannelsen. For syndaktyli der kun bløtdelene er involvert (enkel syndaktyli), oppnås godt funksjonelt resultat, med komplikasjonsrisiko på mindre enn $10 \%$. Syndaktyli der også skjelettet er sammenvokst (kompleks syndaktyli) eller der det finnes ekstra skjelettanlegg mellom to fingerstråler (komplisert syndaktyli), gir dårligere funksjonelt resultat og høyere komplikasjonsrisiko. Gradvis tøyning av vevet ved hjelp av et distraksjonsapparat muliggjør separasjon av fingre man tidligere var tilbakeholden med å skille fra hverandre.

FORTOLKNING Man bør kunne forvente trygg separasjon av fingrene ved kirurgisk behandling, med en god og uavhengig fingerfunksjon. Foreldrene bør informeres om at den kirurgiske behandlingen er en rekonstruktiv prosedyre som kan kreve sekundære korreksjoner.

Termen syndaktyli kommer fra gresk syn (sammen), og daktylos (finger), og refererer til det kliniske utseendet av fingre som ikke har gjennomgått en normal separasjonsprosess i embryonallivet. Det er stor heterogenitet i omfanget av misdannelsen, som kan ha funksjonelle, utviklingsmessige og kosmetiske følger $(1,2)$. I denne artikkelen ønsker vi å gi en oversikt over tilstanden og håndteringen av denne.

\section{Kunnskapsgrunnlag}

Grunnlaget for denne artikkelen er aktuelle lærebøker, deltakelse på internasjonale kongresser, forfatternes kliniske erfaring innen feltet samt artikler funnet ved selektivt litteratursøk i PubMed med bruk av MESH-termene (syndactyly/surgery* OR syndactyly/ methods*). Utvalget ble begrenset til langtidsresultater av operativ behandling publisert $i$ engelskspråklige tidsskrifter i perioden fra og med år 2000 frem til søkedato 18.12. 2012. Artiklene som omhandlet operasjonsresultater var alle basert på enkle pasientserier uten randomisering eller blinding.

\section{Epidemiologi}

Det danske registeret over medfødte misdannelser viste for perioden 1984-93 en insidens for misdannelser i overekstremiteten på 14,6 per 10000 levendefødte (3). Insidensen for syndaktyli var 2,8 per 10000 . Til sammenlikning viser data fra England og Wales at syndaktyli forekommer hos én av hver 2400 levendefødte (4). Tilstanden utgjør omtrent $20 \%$ av alle misdannelser $i$ hånden $(3,5)$ og forekommer dobbelt så hyppig hos gutter. $50 \%$ av syndaktyliene er bilaterale.
Bilateral, enkel syndaktyli mellom lang- og ringfinger er mest vanlig. Involvering av tommel og pekefinger, eller peke- og langfinger er minst vanlig $(6,7)$, bortsett fra som ledd i syndromer (6). Hvilket mellomrom mellom fingrene (web) som er involvert fremgår av figur 1 (8). Kompleks syndaktyli utgjør kun 16,5\% av syndaktyliene (5).

\section{Inndeling}

Inndelingen av syndaktyli fremgår av figur 2. Man bruker betegnelsen enkel syndaktyli hvis kun bløtdelene er involvert og kompleks syndaktyli hvis også skjelettet er sammenvokst (synostose) (1). Betegnelsen inkomplett syndaktyli benyttes hvis det er sammenvoksing til proksimalt for ytterfalangen og komplett hvis syndaktylien fortsetter ut på ytterfalangen. Betegnelsene komplisert syndaktyli benyttes om syndaktyli der det finnes ekstra skjelettanlegg mellom to fingerstråler (gjemt polydaktyli) og akrosyndaktyli om syndaktylier som involverer fingertuppene der det er mellomrom mellom fingrene proksimalt.

\section{Klassifikasjon og etiologi}

Utviklingen av hånden starter dag $27 \mathrm{i} \mathrm{em-}$ bryonallivet $(9,10)$. Fingrene er normalt separert dag 44-46. De fleste syndaktyliene oppstår i denne tidsperioden og skyldes feil i den programmerte celledøden (apoptosen), som normalt tilbakedanner det embryonale interdigitale vevet og som muliggjør danningen av separate fingre $(1,10)$. Dette vevet tilbakedannes normalt fra distalt mot proksimalt og forklarer fenomenet enkel, inkomplett syndaktyli. Unntaket fra regelen er akrosyndaktyli, der den vanligste formen er

\author{
Hebe Désirée Kvernmo \\ hebe.desiree.kvernmo@oslo-universitetssykehus.no \\ Seksjon for overekstremitet- og mikrokirurgi \\ Ortopedisk avdeling \\ Oslo universitetssykehus \\ Jan-Ragnar Haugstvedt \\ Ortopedisk avdeling \\ Sykehuset Østfold, Moss \\ Se også kunnskapsprøve \\ på www.tidsskriftet.no/quiz \\ div \\ Engelsk oversettelse på www.tidsskriftet.no \\ > Se også side 1550
}

\section{HOVEDBUDSKAP}

Syndaktyli bør kartlegges ved barselundersøkelsen og anmerkes i fødselsmeldingen som går til Medisinsk fødselsregister

Barnet må henvises til avdeling med håndkirurgisk ekspertise samt til barnemedisinsk avdeling og genetiker ved assosierte lidelser og anomalier

En god ivaretakelse av foreldrene og grundig informasjon om behandlingsforløpet er nødvendig for å sikre et godt behandlingsresultat

Behandling av syndaktyli er en rekonstruktiv prosedyre, men man bør kunne forvente trygg separasjon, med god og uavhengig fingerfunksjon 


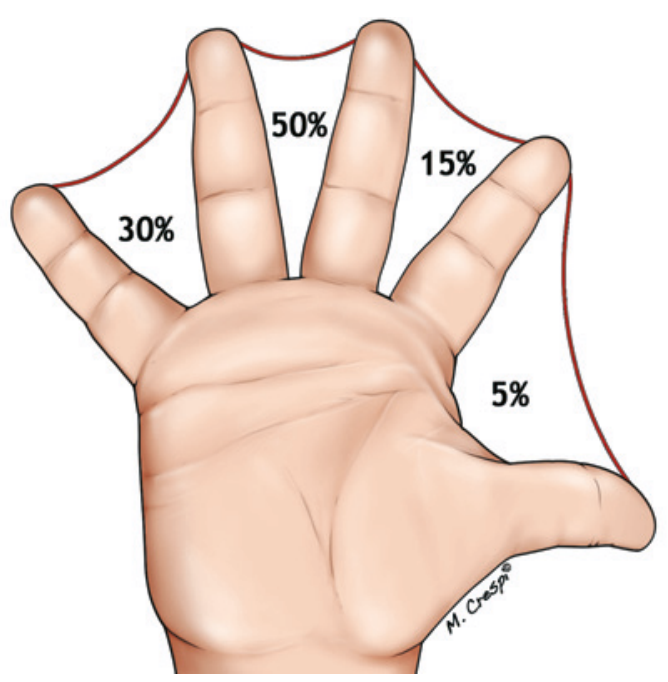

Figur 1 Skjematisk fremstilling av involverte mellomrom mellom fingrene (web) (8)

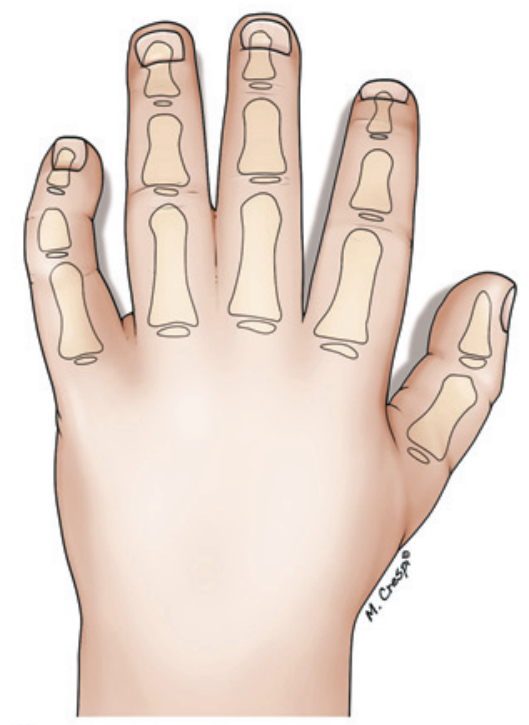

a
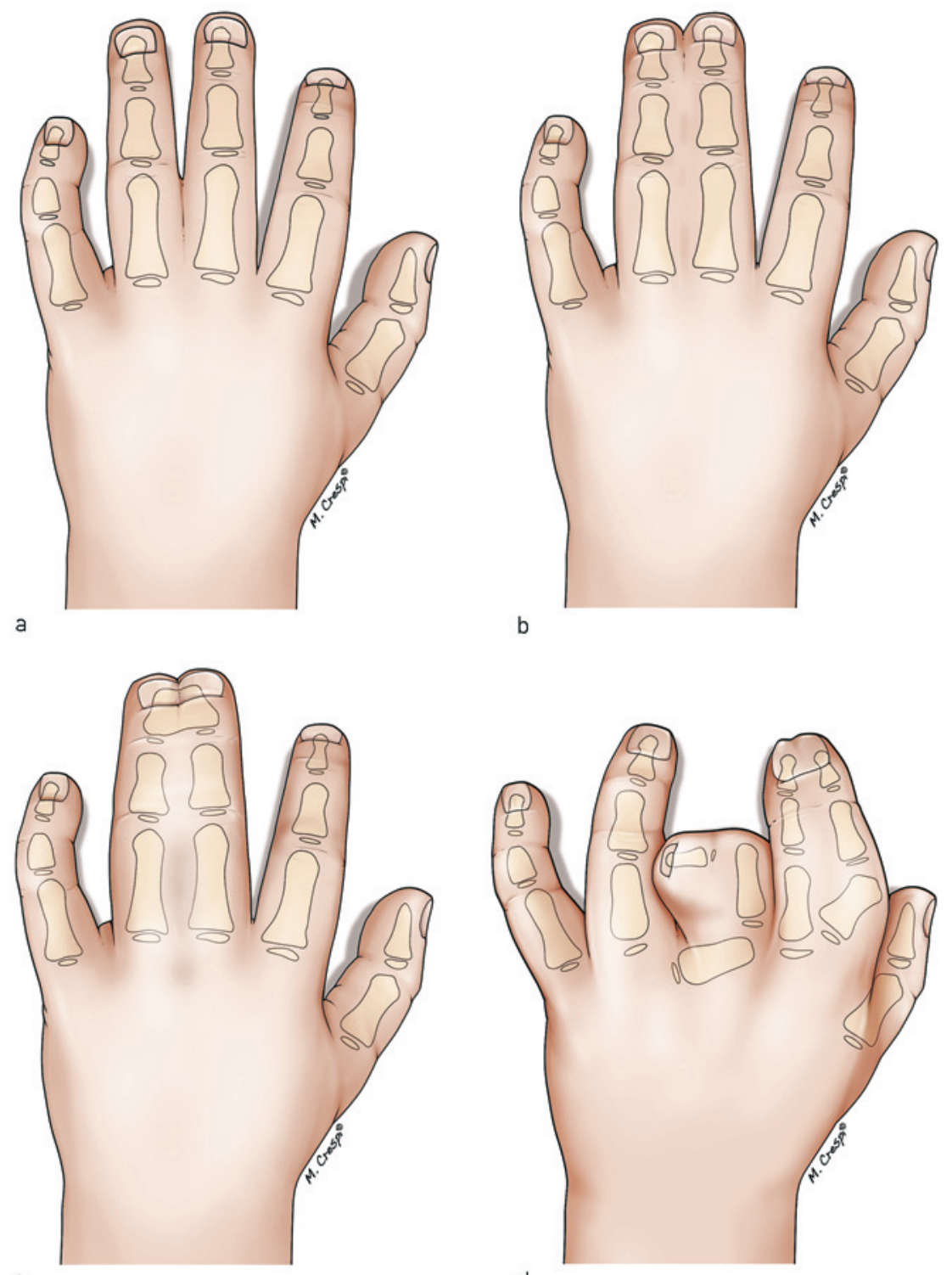

c

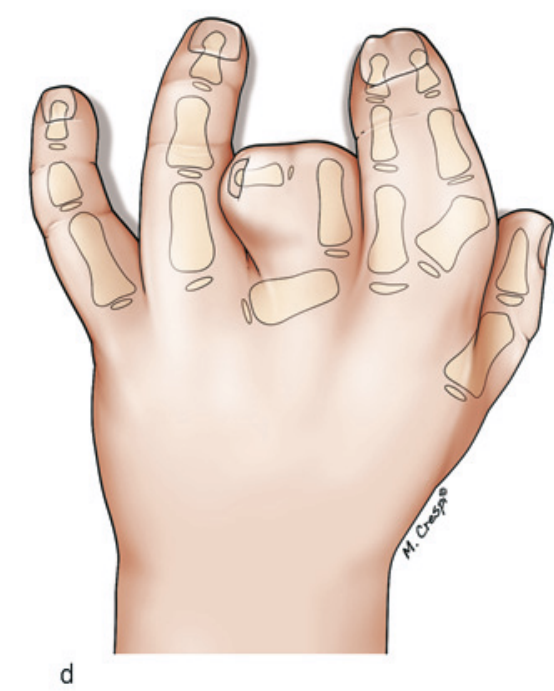

Figur 2 Inndeling av syndaktyli. Syndaktyli mellom lang-og ringfinger. al Enkel, inkomplett syndaktyli b) Enkel, komplett syndaktyli cl Kompleks, komplett syndaktyli d) Komplisert syndaktyli assosiert med et snørefuresyndrom (amniotic ring syndrom), som forårsaker en sammenvoksing av fingre etter avsluttet separasjonsprosess (1). Differensiering av andre organsystemer pågår parallelt med håndens, hvilket forklarer assosierte anomalier ved en del av syndaktyliene $(2,10)$. Den internasjonale håndkirurgiske foreningen (International Federation for Societies for Surgery of the Hand) introduserte i 1976 et klassifiseringssystem der medfødte misdannelser i overekstremiteten klassifiseres i sju kategorier (11). Syndaktyli er plassert i gruppe II sammen med øvrige differensieringsfeil.

Størstedelen av syndaktyliene opptrer isolert og uten kjent årsak. Forhold som kan ha påvirket det intrauterine miljøet, som eksponering for teratogene agens, virusinfeksjoner eller annen sykdom tidlig i svangerskapet, er fremsatt som mulig årsakshypotese (2). $10-40 \%$ av tilfellene har positiv familiehistorie $(1,2,12)$. Når syndaktyli forekommer alene og det er positiv familiehistorie, er syndaktylien alltid arvet autosomalt dominant (1). Ofte er den kompleks og komplisert. Det dominante genet viser imidlertid redusert penetrans og variabel ekspressivitet, slik at tilstanden varierer mye fra generasjon til generasjon (1). Syndaktyli er dessuten en del av minst 28 syndromer. De vanligste er Aperts syndrom, Polands syndrom, snørefuresyndromer og multiple kraniofaciale syndromer (1). Kun $5 \%$ av alle misdannelsene i overekstremiteten er en del av et definert syndrom (2).

\section{Generell barselvurdering}

Når man ser et barn med syndaktyli, må man huske på at andre samtidige misdannelser kan forekomme på grunn av den kronologiske nærheten til håndens embryologiske utvikling $(2,10)$. De enkle syndaktyliene er imidlertid ikke assosiert med andre medfødte misdannelser (2) og fordrer ingen utredning utover den vanlige kartleggingen ved barselundersøkelsen. Hvis det er den komplekse formen og den ikke er arvelig, utvises skjønn. I de fleste tilfeller vil beinet sammenvoksing av et par fingre ikke medføre ytterligere utredning bortsett fra at man gjør en klinisk undersøkelse av hele overekstremiteten, føtter, hode/ansikt og thorax. Mistenker man assosierte tilstander eller at syndaktylien er ledd i et syndrom, henvises barnet til en barnemedisinsk avdeling og genetiker, som bistår i den videre utredningen.

Det er viktig å huske at alle medfødte tilstander som oppdages på barsel- eller nyfødtavdelingen, er meldepliktige til Medisinsk fødselsregister. Meldeplikten gjelder også de mindre omfattende tilstandene, som for eksempel enkel, inkomplett syndaktyli. Der det er uklar diagnose og barnet er henvist til videre utredning, er det viktig at dette anmerkes i fødselsmeldingen. Dette mulig- 
gjør at Medisinsk fødselsregister kan følge opp diagnosesettingen, slik at registerdataene blir mest mulig korrekte. Registerdata basert på nøye anamnestiske opplysninger kan potensielt også bidra til å avdekke årsaksforhold til en del av syndaktyliene.

Barnet bør henvises tidlig til en avdeling med håndkirurgisk ekspertise av hensyn til foreldrenes informasjonsbehov og planlegging og eventuelt behov for koordinering av den videre behandlingen.

\section{Den håndkirurgiske vurderingen}

Ved inspeksjon får man et overblikk over omfanget av involverte fingre. Ved nøyere klinisk undersøkelse vil man kunne skille mellom enkel, kompleks og komplisert syndaktyli. Tilstedeværelsen av aktive leddutslag $\mathrm{i}$ interfalangealleddene med veldefinerte bøye- og strekkefurer indikerer normal leddanatomi og enkel syndaktyli. Hvis det ikke foreligger bøye- og strekkefurer og leddene ikke er bevegelige, må man mistenke kompleks eller komplisert syndaktyli. Manglende bevegelse mellom fingertuppene av to fingerstråler og sammenvokste negler indikerer synostose. Ved syndaktyli assosiert med andre kliniske syndromer som f.eks. Polands syndrom, Aperts syndrom eller snørefuresyndromer er det nødvendig med klinisk undersøkelse av hele overekstremiteten, føtter, hode/ansikt og thorax.

Vanlig røntgen av den affiserte hånden bør alltid inngå i primærvurderingen for å kartlegge eventuelle synostoser, gjemt polydaktyli eller andre skjelettanomalier, og er spesielt viktig ved komplekse syndaktylier.

\section{Vurdering for operativ behandling}

De fleste barna anbefales operasjon $(1,8$, 12-14). Behandlingsmålet er å øke funksjonsnivået. Man vektlegger det kosmetiske aspektet og barnets naturlige tilpasningsevne til misdannelsen. Separasjon av fingre frarådes hvis man ser at dette kan redusere eksisterende funksjonsnivå, f.eks. ved manglende komponenter i de sammenvokste fingrene som umuliggjør å skape uavhengige, stabile og mobile fingre (13). Likeledes kan medisinske forhold gjøre at kirurgi frarådes. Mild, inkomplett syndaktyli uten funksjonelle begrensninger gir kun en relativ operasjonsindikasjon.

\section{Operasjonstidspunkt}

Mens det er få kontroverser rundt indikasjonsstillingen for operasjon, er det et visst skjønn for tidspunktet for operasjon. Spørsmålet som stilles er ikke hvor tidlig inngrepet kan utføres, men heller hvor lenge man kan utsette inngrepet ut fra håndens funksjonelle krav (1). Tidspunktet vurderes individuelt og avhenger av hvilke fingre som er involvert, samt omfanget og kompleksiteten. Likeledes kan det være andre misdannelser som må
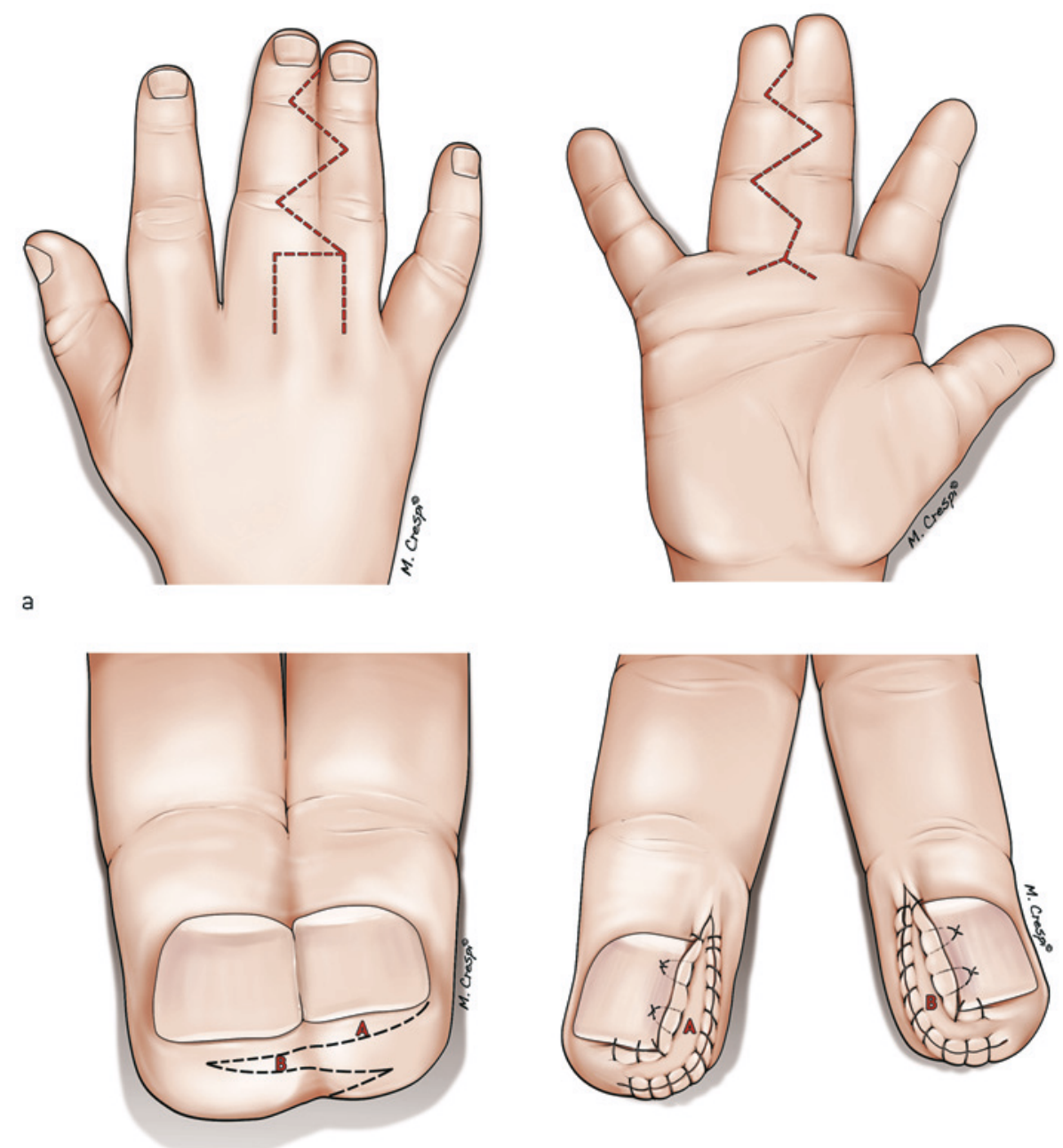

b

Figur 3 Eksempel på plastikk for deling av syndaktyli mellom lang-og ringfinger. a) Planleggingstegning fra volar-og dorsalsiden, der en dorsal rektangulær lapp for mellomrommene og transposisjonslapper ut på fingrene er skissert. b) Planleggingstegning av fingertuppene med transversale pulpalapper og tegning hvor disse er suturert på plass

ivaretas før den operative behandlingen av hånden. Når det kreves flere inngrep, bør disse være utført før skolealder.

Generelt kan man si at enkel syndaktyli i andre og tredje mellomrom mellom fingrene trygt kan deles først i $1-2$ års alder $(1,8,12)$. Kirurgi på en større hånd reduserer risikoen for arrkontraktur og utvikling av svømmehud (webcreep; mellomrommene kryper distalt med veksten).

For syndaktyli i første og fjerde fingermellomrom og syndaktyli med sammenvoksninger av flere fingre anbefaler man kirurgi i 4-9 måneders alder $(1,8,12,15)$. Evnen til å plassere hånden $\mathrm{i}$ rommet og utføre greps- $\mathrm{og}$ klypemanøvrer er kortikale funksjoner som utvikles før ettårsalderen. Koordineringen videreutvikles frem til treårsalderen (16). Best mulig sikring av en normal grepsutvikling skjer således gjennom tidlig operasjon. I tillegg sikrer man best mulig normal utvikling av skjelett og muskulatur.

\section{Informasjon til foreldrene}

Det er viktig å etablere et tillitsfullt forhold til foreldrene. Dette krever tid og kvalifiserte svar på deres spørsmål og bekymring om hva man kan oppnå ved kirurgi samt en presis redegjørelse for hele behandlingsforløpet. Det er viktig å få frem at det ikke alltid er mulig å skape en alminnelig utseende hånd, og at hovedmålet med kirurgien er å løfte barnets funksjonsnivå. Foreldrene bør informeres om at det kan være nødvendig med flere operasjoner for å separere flere sammenvokste fingre. Foreldrene kan ha problemer med å forstå at operasjonen ikke er en enkel deling av to fingre, men en rekonstruktiv prosedyre hvor man blant annet har behov for hudtransplantasjon. Barna bør følges frem til avsluttet vekst slik at utvikling av svømmehud og kontraktur langs arret ut på fingeren kan korrigeres før barnet utvikler deformiteter.

Flere av våre universitetsklinikker har 

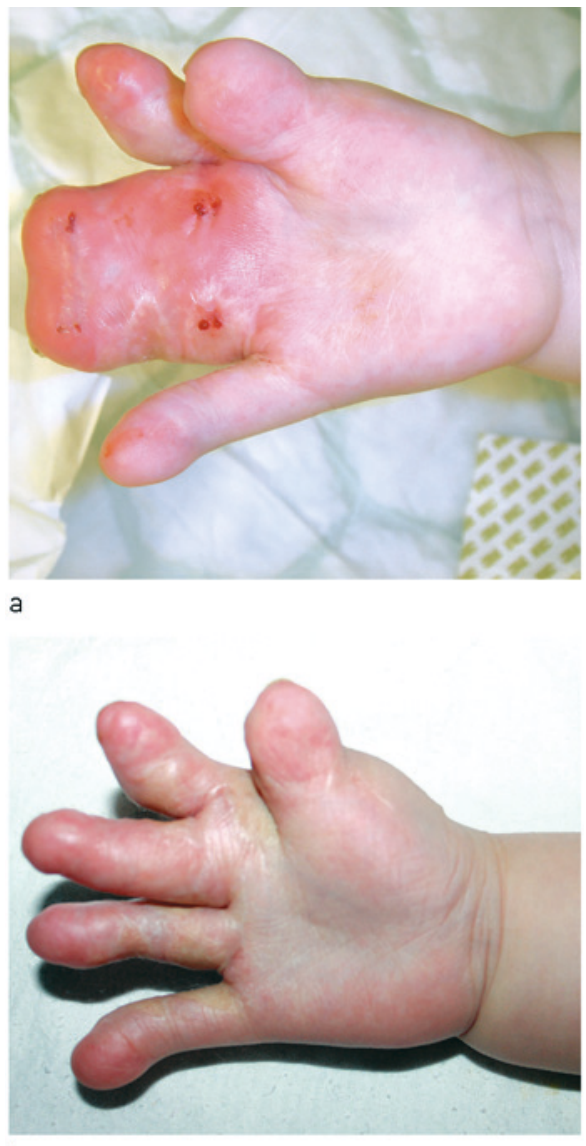

Figur 4 Vevsekspansjon ved hjelp av eksternt distraksjonsapparat («magic cube») hos pasient med kompleks syndaktyli. Foto sett fra volarsiden av høyre hånd hos pasient med Aperts syndrom som har fått separert kompleks syndaktyli mellom alle fingrene utenom mellom lang-og ringfinger. a) Foto etter fjerning av «magic cube». b) Foto sett fra volarsiden ca. ett år etter separasjon av lang-og ringfinger. Pasientens pårørende har gitt samtykke til at bildene blir publisert

tverrfaglige dysmeliteam bestående av håndkirurg, ergoterapeut og ortopediingeniør for å ivareta de mer komplekse tilstandene. Teamene sørger for å gi informasjon, og foreldre og barn får dessuten møte andre barn med samme eller liknende lidelser og deres foreldre. Slik ivaretas også mestringsaspektet.

\section{Operasjon}

Hvert steg i den operative prosedyren er designet for å minimere komplikasjonsrisikoen. Kirurgien utføres i generell anestesi med blodtomhet og bruk av lupebriller, og man må ha mikroinstrumenter tilgjengelig. Hvis tilstanden er bilateral, utføres inngrepet ofte samtidig på begge hender. De ulike teknikkene for separering av sammenvokste fingre baseres stort sett på de samme prinsippene. Det bør ikke opereres på begge sider av en finger samtidig, da dette kan kompromittere sirkulasjonen $(1,2,12)$. Eksempel på plastikk for deling av syndaktyli er vist i figur 3a. Blodtomheten slippes opp etter at utløsningen av lappene er ferdig, og man gjør hemostase før lappene sys på plass med resorberbar sutur. Huddefekter dekkes med fullhud, oftest høstet fra lysken. Man unngår bruk av delhudstransplantater, siden disse kan skrumpe opptil $50 \%$ og dermed medføre arrkontrakturer (13). Ved syndaktyli ut til fingertuppene rekonstrueres negleranden med transversale fingertupplapper (fig 3b) $(14,17)$.

Dersom alle fingrene er sammenvokste, separerer man ved første operasjon tommel og pekefinger samt lang- og ringfinger. Ved andre operasjon, vanligvis 4-6 måneder senere, separerer man peke- og langfinger samt ring- og lillefinger $(12,15)$.

Ved syndaktyli hos barn med Aperts syndrom kan det være nyttig å dekke første fingermellomrom med en dreielapp fra dorsale håndrygg $(1,14,15)$. Ved slike omfattende syndaktylier kan man gjøre vevsdistraksjon ved hjelp av et eksternt distraksjonsapparat (Cube fix distractor; utviklet av Rolf Habenicht ved Kinderkrankenhaus Wilhelmstift i Hamburg) før man separerer de siste to fingrene (lang- og ringfinger) (fig 4) $(18,19)$. Apparatet omtales som «magic cube» ved Oslo universitetssykehus, siden distraksjonen medfører «ekstra» hud som gjør påfølgende separasjon enklere.

\section{Behandlingsresultater}

Det er vanskelig å gi eksakte data om behandlingsresultater, grunnet tilstandens heterogenitet, de mange kirurgiske teknikkene og de få publiserte langtidsresultatene.

Ved enkle syndaktylier oppnår man godt funksjonelt og kosmetisk resultat (12, 20-22). Det er midlertid rapportert rundt $10 \%$ behov for sekundære inngrep (12). Utvikling av svømmehud er vist $i$ to av 26 opererte fingermellomrom etter 18 års oppfølgingstid ved teknikk med fullhudstransplantat (21). For transplantatfri teknikk viser langtidsresultater etter mer enn ti års oppfølging noe høyere forekomst av svømmehudutvikling (22).

Goldfarb og medarbeidere (23) påviste gode bevegutslag etter separasjonen av kompleks syndaktyli mellom enten lang- og ringfinger eller mellom ring- og lillefinger. Imidlertid fant man rotasjons- og aksedeviasjon av fingrene samt negledeformitet med inadekvat lateral neglerand på de fleste av fingrene. Studien understøttes av Vekris og medarbeidere (24), som fant at kompleks og komplisert syndaktyli samt forsinket separasjon, resulterer i dårligere resultater. I en studie av Aperts syndrom uten bruk av distraksjon fant man akseptable funksjonelle resultater (25). Samtlige pasienter hadde behov for korrigerende prosedyrer, men revisjonsbehovet tatt tilstandens kompleksitet $\mathrm{i}$ betraktning ble ansett som akseptabelt.
Resultatene ved bruk av «magic cube» for separasjon av de siste to fingrene er gode (18, 19). Man klarte å skape en «femfinger»-hånd med tilsvarende utseende av lang- og ringfinger som de øvrige separerte fingrene. Av åtte syndaktylioperasjoner (19) var det to mindre infeksjoner som kun ble behandlet med antibiotika, og en infeksjon etter fullendt distraksjon, der man måtte fjerne distraksjonsapparatet. I dette tilfellet ble syndaktylioperasjonen utsatt $i$ tre uker. I ett tilfelle vokste den delte synostosen sammen igjen under distraksjonen og måtte reopereres.

De vanligste postoperative komplikasjonene i forbindelse med syndaktylioperasjoner er infeksjon og transplantat- eller lappemaserasjon som kan medføre tap av transplantat og lapp. Tap av finger er sjelden, men er beskrevet i litteraturen (12).

\section{Avsluttende kommentarer}

Vi presenterer en oversikt over viktige prinsipper i håndteringen av barn med syndaktyli, der hovedindikasjonen for kirurgi er å bedre håndens funksjonsnivå. Til tross for at syndaktyli er en av de vanligste medfødte misdannelsene i overekstremiteten, er kunnskapsgrunnlaget beskjedent, siden tilstanden er heterogen og rammer få pasienter. Vi presenterer behandlingsresultater basert på enkle pasientserier uten randomisering. Studiene konkluderer med at man kan forvente trygg separasjon av fingrene, med god og uavhengig fingerfunksjon. Behandlingsresultatet er best for de minst omfattende tilstandene. For barn med assosierte lidelser og anomalier er det hensiktsmessig at behandlingsstedet har alle nødvendige spesialiteter. Grundig informasjon til foreldre er viktig. Foreldrenes forståelse av behandlingsforløpet og aksept for hva man kan forvente seg av resultater er nødvendig for barnets mestring av tilstanden.

\section{Hebe Désirée Kvernmo (f. 1961)}

er spesialist i håndkirurgi og ortopedisk kirurgi, dr.med. og MHA. Hun er overlege og leder av Norsk forening for håndkirurgi.

Forfatter har fylt ut ICMJE-skjemaet og oppgir ingen interessekonflikter.

\section{Jan-Ragnar Haugstvedt (f. 1954)}

er spesialist i generell- og ortopedisk kirurgi, og i håndkirurgi. Ph.d.-graden ble sluttført etter et forskningsopphold ved Mayo Clinic. Han er overlege og styremedlem i Norsk forening for håndkirurgi og visegeneralsekretær i European Wrist Arthroscopy Society.

Forfatter har fylt ut ICMJE-skjemaet og oppgir ingen interessekonflikter. 


\section{Litteratur}

1. Flatt AE. Webbed fingers. I: Flatt AE, red. The care of congenital hand anomalies. St. Louis, MO: Quality Medical Publishing, 1994: 228-75.

2. Upton J. Congenital anomalies of the hand and forearm. I: McCarthy JG, red. Plastic surgery. New York, NY: WB Saunders, 1990; 8: 5218-398.

3. Larsen CF. Demography and social impact. I: The growing hand. Gupta A, Kay SPJ, Scheker LR, red. London: Mosby, 2000; 18: 121-4.

4. Office for National Statistics. Congenital malformation statistics-notifications 1993. London: HMSO, 1996: 1-4

5. De Smet L. Classification for congenital anomalies of the hand: the IFSSH classification and the JSSH modification. Genet Couns 2002; 13: 331-8.

6. Kettelkamp DB, Flatt AE. An evaluation of syndactylia repair. Surg Gynecol Obstet 1961; 113: 471-8

7. Nylen B. Repair of congenital finger syndactyly. Acta Chir Scand 1957; 113: 310-8.

8. Waters PM, Bae DS. Syndactyli. I: Waters PM, Bae DS, red. Pediatric hand and upper limb surgery. A practical guide. Philadelphia, PA: Lippincott Williams \& Wilkins, 2012; 2: 12-25.

9. Tickle C. Embryology. I: Gupta A, Kay SPJ, Scheker $L R$, red. The growing hand. London: Mosby, 2000; 5: $25-32$

10. Waters PM, Bae DS. Embryology and development I: Waters PM, Bae DS, red. Pediatric hand and upper limb surgery. A practical guide. Philadelphia, PA: Lippincott Williams \& Wilkins, 2012; 1 : $1-11$
11. Knight SL, Kay SPJ. Classification of congenital anomalies. I: Gupta A, Kay SPJ, Scheker LR, red The growing hand. London: Mosby, 2000; 19: $125-36$

12. Dao KD, Wood VE, Billings A. Treatment of syndac tyly. Tech Hand Up Extrem Surg 1998; 2: 166-77.

13. Ezaki M. Syndactyly. I: Green DP. Hotchkiss RN Pederson WC, red. Green's operative hand surgery. Philadelphia, PA: Churchill Livingstone, 1999: 414-29

14. Buck-Gramcko D. Congenital malformations. I: Nigst H, Buck-Gramcko D, Millesi H et al, red. Hand surgery. New York, NY: George Thieme, 1998; 12: $1-114$

15. Smith P, Laing H. Syndactyly. I: Gupta A, Kay SPJ, Scheker LR, red. The growing hand. London: Mosby, 2000; 29: 225-30.

16. Erhardt RP, Lindley SG. Functional development of the hand. I: Gupta A, Kay SPJ, Scheker LR, red The growing hand. London: Mosby, 2000; 11: $71-81$.

17. Lundkvist $L$, Barfred T. A double pulp flap technique for creating nail-folds in syndactyly release. J Hand Surg [Br] 1991; 16: 32-4.

18. Bye K, Haugstvedt JR. Behandling av syndactyli. Abstrakt 196. Oslo: Norsk kirurgisk forening, 2004 www.grafiskpartner.no/hostmotet/2004/ frie_foredrag_190-201.htm (13.5.2013).

19. Nachemson A, Hessman P. Reconstruction of Apert hands with Cube fix distractor. Abstrakt. Hamburg: 8th World Symposium on Congenital Malformations of the Hand Upper Limb, 2009.
20. Kvernmo HD. Behandling av syndactyli ved Ullevål. Abstrakt 121. Høstmøteboken. Oslo: Norsk ortopedisk forening, 2009: 119

21. Lumenta DB, Kitzinger HB, Beck $\mathrm{H}$ et al. Longterm outcomes of web creep, scar quality, and function after simple syndactyly surgical treatment. J Hand Surg Am 2010; 35: 1323-9.

22. Niranjan NS, Azad SM, Fleming ANM et al. Longterm results of primary syndactyly correction by the trilobed flap technique. Br J Plast Surg 2005. 58: 14-21.

23. Goldfarb CA, Steffen JA, Stutz CM. Complex syndactyly: aesthetic and objective outcomes. J Hand Surg Am 2012; 37: 2068-73.

24. Vekris MD, Lykissas MG, Soucacos PN et al. Congenital syndactyly: outcome of surgical treatment in 131 webs. Tech Hand Up Extrem Surg 2010; 14: 2-7.

25. Roje Z, Roje Z, Ninkovi? M et al. Reconstruction of the hand in Apert syndrome: two case reports and a literature review of updated strategies for diagnosis and management. Acta Chir Plast 2012; 54: $13-8$

Mottatt 1.2. 2013, første revisjon innsendt 24.3. 2013, godkjent 13.5. 2013. Medisinsk redaktør Trine B. Haugen. 